\title{
Thymol May be an Effective Agent in the Treatment of Liver and Kidney Damages Caused by lonizing Radiation
}

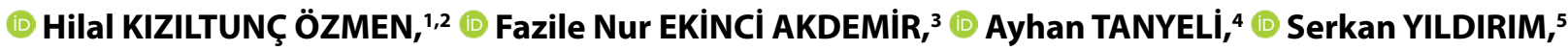 \\ (1) Yasin BAYIR, ${ }^{6}$ (D) Yılmaz ŞAHIN, 7 (D) Gizem ESER, ${ }^{5}$ (D) Ayşenur KAHRAMANLAR ${ }^{6}$
}

\author{
'Department of Radiation Oncology, Atatürk University Faculty of Medicine, Erzurum-Turkey \\ ${ }^{2}$ Department of Anesthesiology and Reanimation, Atatürk University Faculty of Medicine, Anethesiology Clinical Research Office, \\ Erzurum-Turkey \\ ${ }^{3}$ Department of Nutrition and Dietetics, Ağrı İbrahim Cecen University, Faculty of Health Sciences, Agrı-Turkey \\ ${ }^{4}$ Department of Physiology, Atatürk University Faculty of Medicine, Erzurum-Turkey \\ ${ }^{5}$ Department of Pathology, Atatürk University Faculty of Veterinary, Erzurum-Turkey \\ ${ }^{6}$ Department of Biochemistry, Atatürk University Faculty of Pharmacy, Erzurum-Turkey \\ ${ }^{7}$ Department of Physics, Atatürk University Faculty of Science, Erzurum-Turkey
}

\begin{abstract}
OBJECTIVE
The goal of the present study was to evaluate the therapeutic efficacy of thymol in diminishing the damages to the liver and kidney tissues caused by the application of ionizing radiation.

\section{METHODS}

The experimental rats were randomized and grouped as follows: Group I (control), Group II (receiving ionizing radiation), and Group III (receiving thymol + ionizing radiation). Pathological tissue damage was assessed by immunohistochemical and biochemical analyses using chemical methods.

\section{RESULTS}

The level of plasma malondialdehyde (MDA) in both the tissues were significantly elevated in Group II compared to that in Group I ( $\mathrm{p}<0.001$ for both the tissues), but they were significantly lower in Group III than in Group II ( $\mathrm{p}<0.01$ for both the tissues). In addition, the plasma MDA level in both the tissues was increased in Group III than in Group I ( $\mathrm{p}<0.05$ for both the tissues). The level of superoxide dismutase (SOD) and glutathione (GSH) in the liver and kidney tissues were significant decreased in Group II than in Group I ( $<<0.001$ for both the tissues and for both the parameters), while these parameters were increased in Group III relative to those in Group II ( $\mathrm{p}<0.05$ for both the tissues and for both the parameters). Moreover, the plasma SOD and GSH levels in both the tissues were decreased in Group III than in Group I ( $\mathrm{p}<0.05$ for both the tissues and for both the parameters). All these findings were supported by the pathological images of caspase-3 and 8-OHdG tests conducted in the study.
\end{abstract}

\section{CONCLUSION}

Our results demonstrated that the treatment of thymol in the rat models is useful in diminishing the liver and kidney damages caused by the application of ionizing radiation.

Keywords: Caspase-3; ionizing radiation; livers; kidneys; thymol; 8-OHdG.

Copyright $\odot$ 2021, Turkish Society for Radiation Oncology

Dr. Hilal KIZILTUNÇ ÖZMEN

Atatürk Üniversitesi Tıp Fakültesi,

Radyasyon Onkolojisi Anabilim Dalı,

Erzurum-Turkey

E-mail: hkiziltuncozmen@hotmail.com 


\section{Introduction}

The direct exposure of liver tissues to ionizing radiation induced ionization and arousal in the atoms and molecules constituting the cells and tissues. In the subsequent chemical processes, the damaged atoms and molecules react with other cellular structures to trigger the emergence of free radicals. Such molecular changes induces biological processes, including various enzymatic reactions due to the effect of radiation on living structures. These events cause metabolic changes that conclude in cell death. The toxic effects on healthy cells of radiation therapy used in the tumor treatment are believed to be capable of reduction by agents possessing various biological properties.[1-3] Thymol is a natural phenolic compound present in various medicinal plants.[4] It exhibits numerous useful functions such as radioprotective effects, inflammatory response inhibition, genotoxicity, and mutagenicity. $[5,6]$ Until date, no previous studies had demonstrated the efficacy of thymol in various different biological properties and in models of ionizing radiation-induced organ damage. From this perspective, the concept of the present research is entirely original. Our study goal was to evaluate the efficacy of thymol in declining the damage to liver and kidney tissues caused by the application of ionizing radiations.

\section{Materials and Methods}

The animals used in the experimental studies were sourced from the Experimental Animal Research and Application Center (ATADEM) and were housed under the same laboratory conditions of 12 -h day/12-h night; $55 \%$ moisture; $22{ }^{\circ} \mathrm{C} \pm 2{ }^{\circ} \mathrm{C}$ temperature. The animals received standard pellet feed and tap water during the experimental period.

\section{Experimental Procedures}

A total of 30 female Wistar rats were categorized into 3 groups. The experimental groups and the protocol are summarized as follows: Group I (control group): Including rats that did not receive any treatment. Group II (ionizing radiation group): Including rats that were anesthetized with ketamine/xylazine, after which 8 Gray external irradiation was applied to their abdominal regions. Radiotherapy was applied using the 13.6 Version Varian Trilogy Device (Series No: 6196 USA). After approximately $36 \mathrm{~h}$ of the irradiation, these rats were sacrificed with high-dose anesthesia, and their liver and kidney tissues were quickly removed. Group III (thymol + ionizing radiation group): Including rats that received thymol ( $7.5 \mathrm{mg} / \mathrm{kg}$ body weight) prepared in $0.5 \% \mathrm{DMSO}$ and administered orally once a day for 14 days through an intragastric tube. The ionizing radiation was applied $12 \mathrm{~h}$ following the administration of the last thymol dose. The thymol dose was selected as suggested elsewhere.[7]

\section{Histopathological and Immunohistochemical Pro- cedures}

Immediately after necropsy, the kidney and liver tissue samples were placed in formalin solution for $48 \mathrm{~h}$ for histopathological evaluation. They were then stained with hematoxylin-eosin stain and examined under a light microscope (DM 1000; Leica, Germany). All specimens intended for immunoperoxidase assay were passed through graded xylol and alcohol series. Phosphatebuffered saline (PBS) was then applied to the sections and placed into $3 \% \mathrm{H}_{2} \mathrm{O}_{2}$ for 10 min for endogenous peroxidase inactivation. In order to reveal the antigen contained in the tissues, the specimens were permitted to cool together with a retrieval solution, following processing in a microwave oven for $2 \times 5 \mathrm{~min}$ at 500 watts. The tissues were incubated with caspase- 3 and $8-\mathrm{OHdG}$ (Catalog no: sc-56053, sc-66036 Santa Cruz, USA) at 60 min with an apoptotic marker at $37^{\circ} \mathrm{C}$. An immunohistochemistry kit (AbcamHRP/DAB Detection IHC kit) was used as per the manufacturer's instructions. 3-3-Diaminobenzidine (DAB) was used as the chromogen. Hematoxylin was applied for soil staining. The sections were classified as either non-positive $(-)$, mild $(+)$, moderate $(++)$, severe $(+++)$, or very severe $(++++)$.

\section{Biochemical Procedures}

Immediately after collection, the kidney and liver tissues were washed in cold saline and stored at $-80^{\circ} \mathrm{C}$. Briefly, the tissues were crushed in liquid nitrogen using the Tissue Lyser II Grinding Jar Set (Qiagen, Hilden, Germany). Approximately $50 \mathrm{mg}$ of the sample was homogenized in $1 \mathrm{~mL}$ of PBS homogenate buffer inside an Eppendorf tube by using the Tissue Lyser II set, followed by centrifugation. The SOD, GSH, and MDA levels of the homogenates were determined by ELISA (Enzyme-Linked ImmunoSorbent Assay), as described in some previous studies.[8-10]

\section{Statistical Analysis}

One-way analysis of variance and Duncan's test were applied for the analysis of the oxidant and antioxidant parameters. At histopathological examination, the Kruskal-Wallis test was applied to compare the differences between semi-quantitative data and the Mann- 
Whitney U-test so as to compare the binary groups. The SPSS 13.0 software was used for all analyses. The results were expressed as mean \pm standard deviation $($ mean $\pm S D)$. The $P$ values of 0.05 were considered to be statistically significant.

\section{Results}

\section{Histopathological Findings in the Liver Tissues}

Group I: The examination of liver tissues revealed a normal histological structure (Fig. 1a). Group II: Mild coagulation necrosis was recorded in the hepatocytes, moderate hydropic degeneration in the hepatocytes, and dilatation and hyperemia in the sinusoids (Fig. 1b). Group III: Although mild hydropic degeneration was recorded, no necrotic cells were detected. Sinusoidal dilatation and hyperemia were present (Figure 1c). Tissue damage was significantly lower in Group III than in Group II $(\mathrm{p}<0.05)$. Histopathological data are shown in Table 1.

\section{Histopathological Findings for the Kidney Tissues}

Group I: The kidney tissues exhibited a normal histological structure (Fig. 2a). Group II: The renal tissues exhibited severe hydropic degeneration and moderate coagulation necrosis, together with hyperemia in the interstitial vessels (Fig. 2b). Group III: Mild hydropic degeneration was noted in the renal tissues (Fig. 2c). The severity of damage was lower in Group III than in Group II $(\mathrm{p}<0.05)$. Histopathological data are shown in Table 1.

Immunohistochemical Findings in the Liver Tissues Group I: No expression of caspase-3 was detected on immunohistochemical examination of the liver tissues (Fig. 3a). Group II: Severe cytoplasmic caspase-3 expression was observed in the hepatocytes (Fig. 3b). Group III: Mild expression of caspase-3 was observed (Fig. 3c). However, immunopositivity decreased significantly when compared to that in Group II $(\mathrm{p}<0.05)$. Histopathological data are shown in Table 1.

\section{Immunohistochemical Findings in the Kidney Tis- sues}

Group I: Immunohistochemical examination of the renal tissues revealed no 8-OHdG expression (Fig. 4a). Group II: Severe expression of intracytoplasmic 8-OHdG was observed in the tubular epithelium (Fig. 4b). Group III: Mild expression of intracytoplasmic 8-OHdG was observed (Fig. 4c). The immunopositivity decreased significantly when compared with that in Group II $(\mathrm{p}<0.05)$. Histopathological data are shown in Table 1.

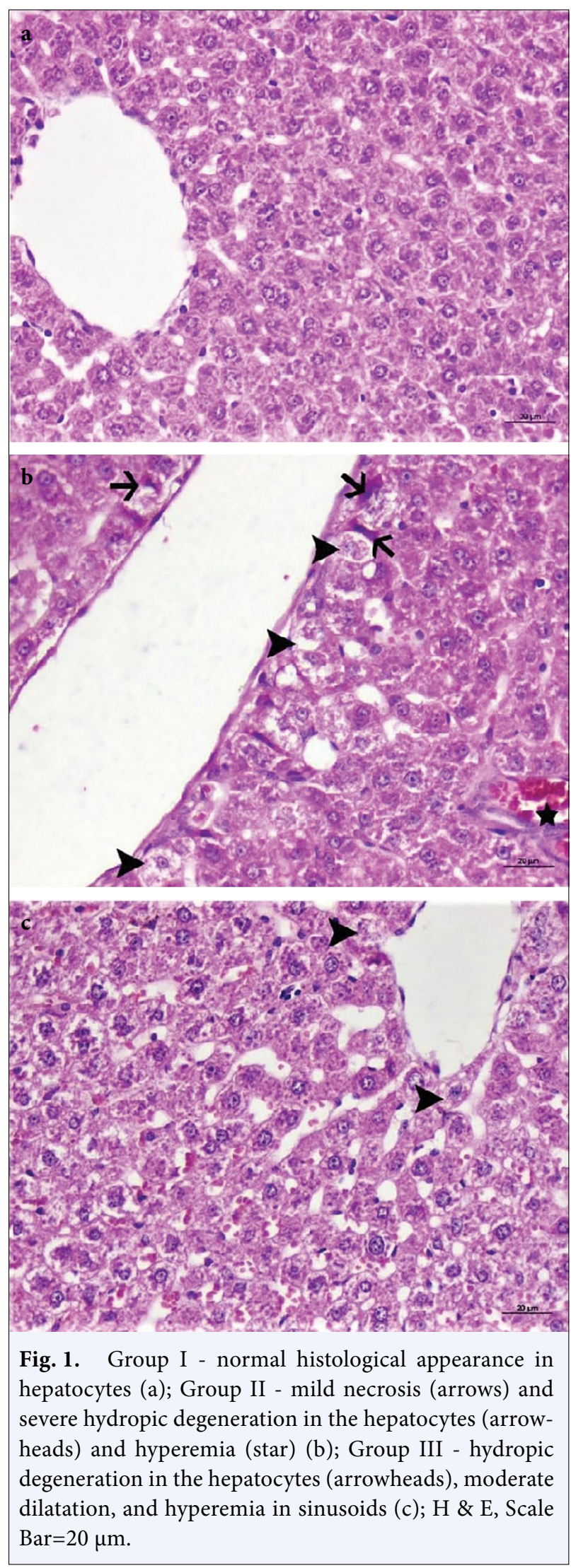




\begin{tabular}{|c|c|c|c|c|}
\hline \multirow[t]{2}{*}{ Table 1} & \multicolumn{4}{|c|}{$\begin{array}{l}\text { Histopathological and immunohistochemical } \\
\text { findings in liver and kidney tissues }\end{array}$} \\
\hline & & Group I & Group II & Group III \\
\hline \multicolumn{5}{|l|}{ Liver } \\
\hline \multicolumn{2}{|c|}{$\begin{array}{l}\text { Degeneration in } \\
\text { hepatocytes }\end{array}$} & - & +++ & ++ \\
\hline \multicolumn{2}{|c|}{ Necrosis in hepatocytes } & - & ++ & - \\
\hline \multicolumn{2}{|c|}{ Hyperemia in vessels } & - & +++ & ++ \\
\hline \multicolumn{2}{|c|}{ Caspase-3 (Liver) } & - & ++ & + \\
\hline \multicolumn{5}{|l|}{ Kidney } \\
\hline \multicolumn{2}{|c|}{$\begin{array}{l}\text { Degeneration in tubular } \\
\text { epithelium }\end{array}$} & - & +++ & + \\
\hline \multicolumn{2}{|c|}{$\begin{array}{l}\text { Necrosis in tubular } \\
\text { epithelium }\end{array}$} & - & ++ & - \\
\hline \multicolumn{2}{|c|}{ Hyperemia in vessels } & - & +++ & ++ \\
\hline \multicolumn{2}{|c|}{8 OHdG (Kidney) } & - & +++ & + \\
\hline
\end{tabular}

\section{Biochemical Results for the Liver and Kidney Tis- sues}

The parameter values of the rat groups are expressed as mean \pm SD in Table 2. The level of plasma malondialdehyde (MDA) in the liver and kidney tissues were found to be significantly elevated in Group II than in Group I $(\mathrm{p}<0.001$ for both the tissues), but they were significantly lower in Group III than in Group II ( $p<0.01$ for both the tissues). Moreover, the plasma MDA level in both the tissues was increased in Group III than in Group I ( $\mathrm{p}<0.05$ for both the tissues). The level of superoxide dismutase (SOD) and glutathione (GSH) in the liver and kidney tissues were significant decreased in Group II than in Group I $(\mathrm{p}<0.001$ for both the tissues and for both the parameters), while these parameters were increased in Group III than in Group II ( $p<0.05$ for both the tissues and for both the parameters). Furthermore, the plasma SOD and GSH levels in both the tissues were decreased in Group III than in Group I ( $p<0.05$ for both the tissues and for both the parameters).

\section{Discussion}

In this study, while the antioxidant activity was decreased due to ionizing radiation application, the level of the oxidant agents was increased in the experimental rats. Moreover, the expression of caspase- 3 and 8 -OHdG were also aggravated in the rats. However, it was observed that these abnormal results could be corrected by thymol treatment in the experimental groups. All these findings are supported by the relevant pathological imaging data in the study. Both healthy
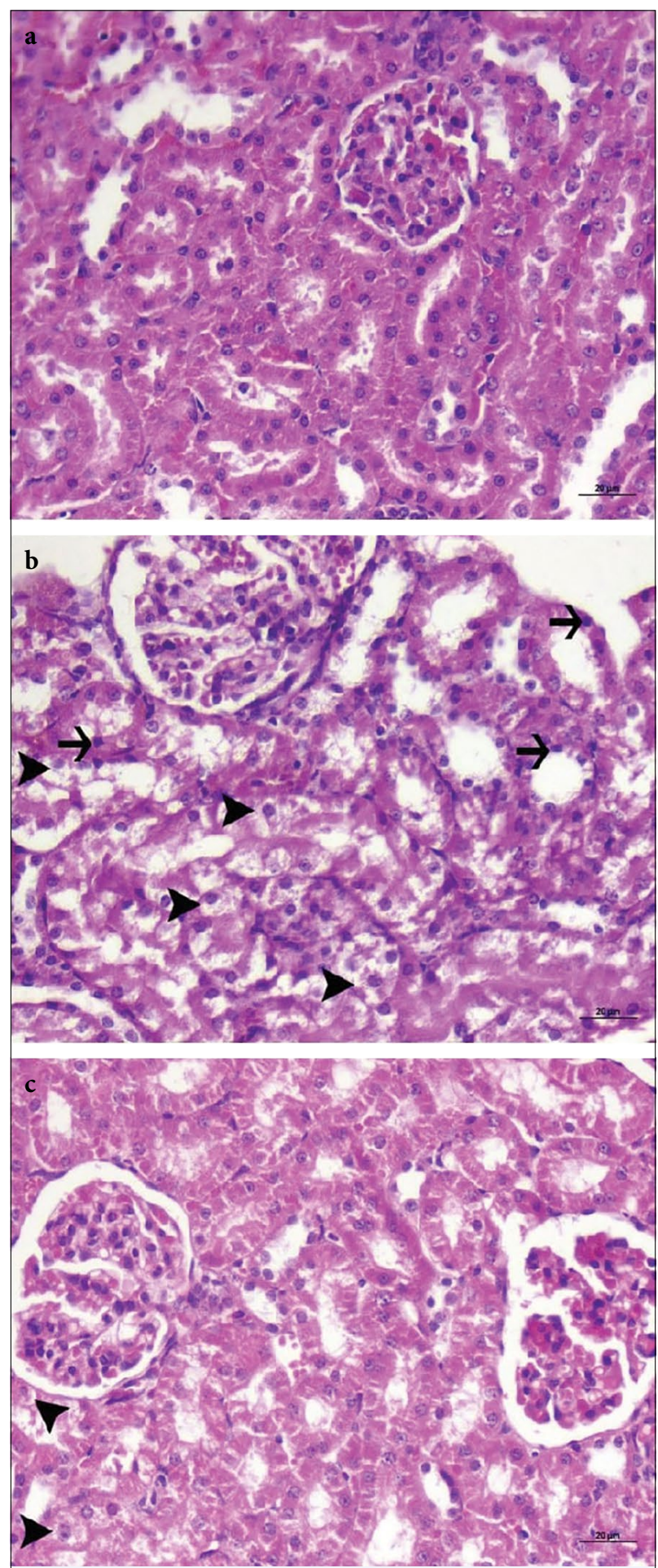

Fig. 2. Group I - normal histological appearance in the renal tissues (a); Group II - moderate necrosis in the tubular epithelium (arrows) and severe hydropic degeneration in the tubular epithelium (arrowheads) (b); Group III - mild hydropic degeneration in the tubular epithelium (arrows); (c) $-\mathrm{H} \& \mathrm{E}$, Scale bar $=20 \mu \mathrm{m}$. 

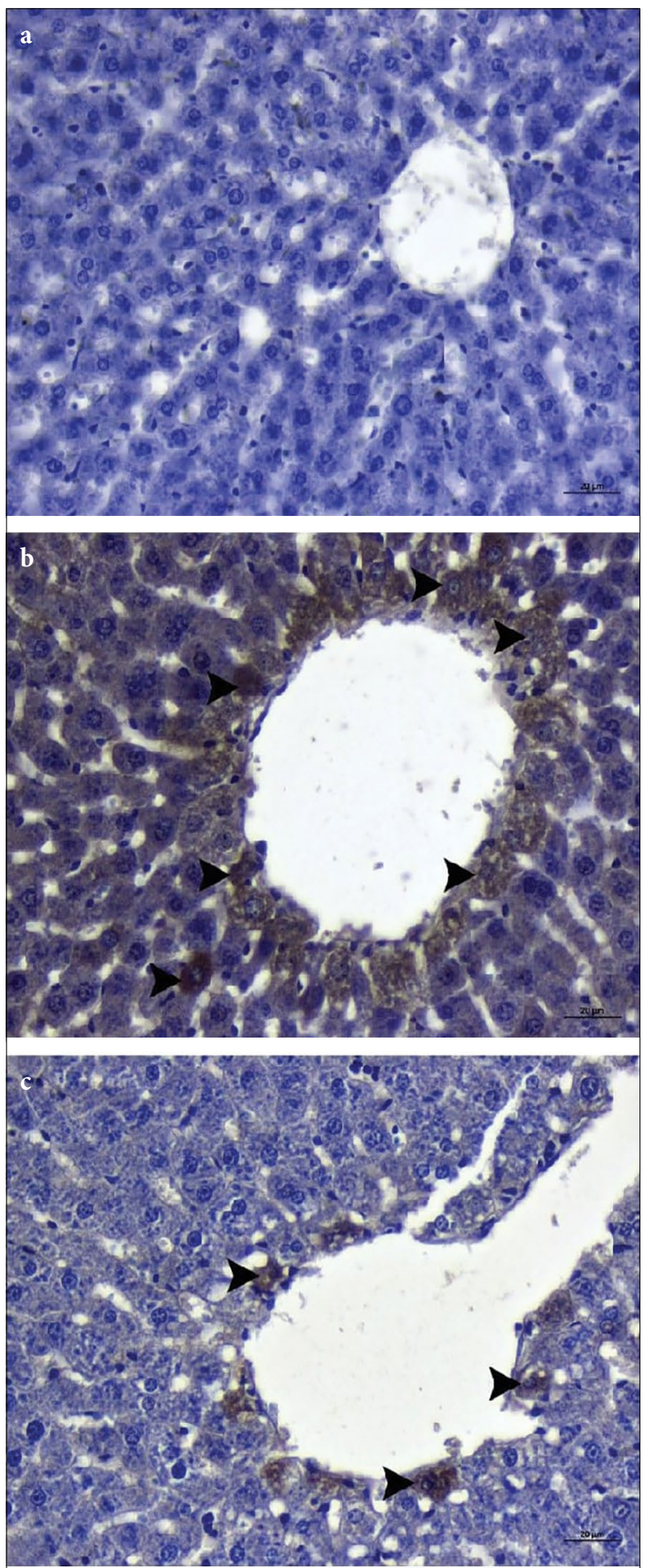

Fig. 3. Group I- liver tissue caspase-3 expression negative (a); Group II - moderate expression of hepatoplasmic caspase- 3 in the hepatocytes (arrowheads); (b) Group III - mild expression of caspase- 3 in the hepatocytes (arrowheads); (c) - IHC-P, Scale bar $=20 \mu \mathrm{m}$.
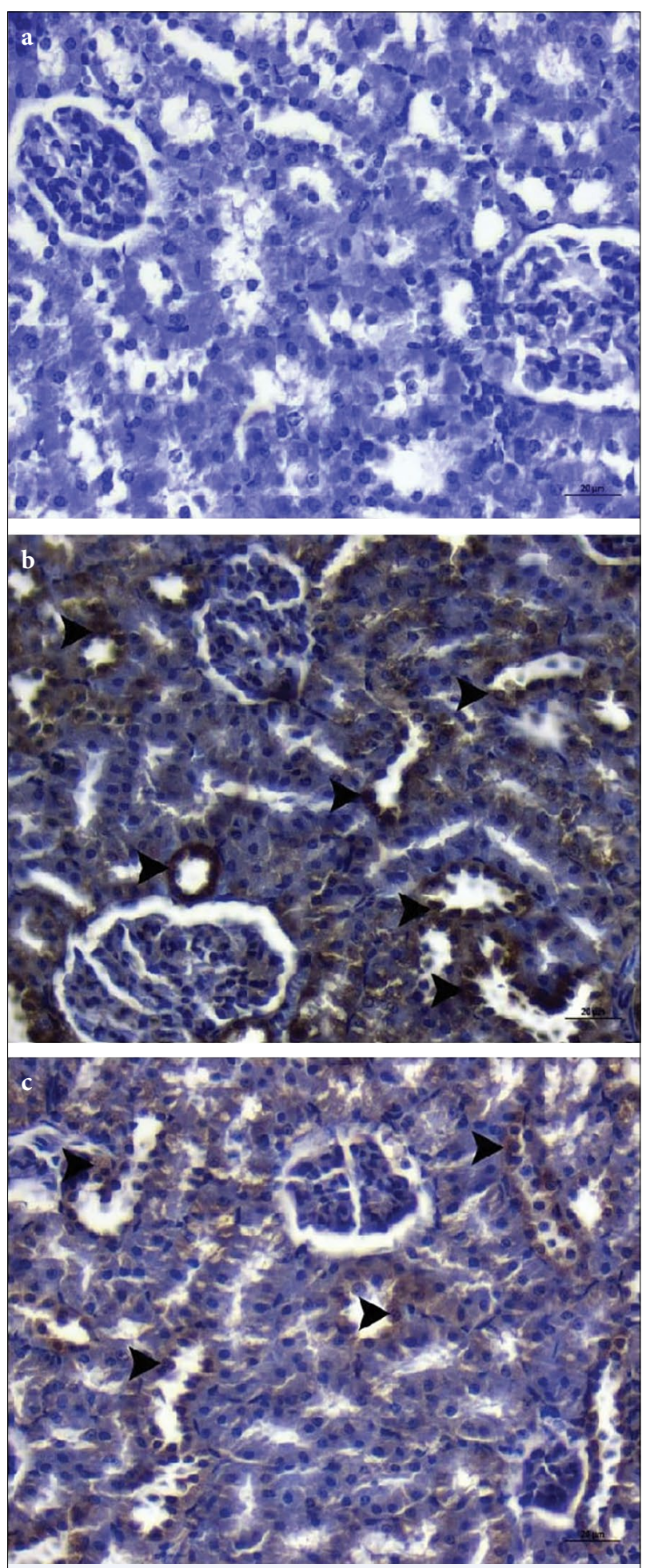

Fig. 4. Group I - kidney tissue 8-OHdG expression negative (a); Group II - severe cytoplasmic 8-OHdG expression in the tubular epithelium (arrows) (b); Group III - mild cytoplasmic 8-OHdG expression in the hepatocytes (arrowheads); (c) - IHC-P, Scale bar $=20 \mu \mathrm{m}$. 
Table 2 Superoxide dismutase, glutathione and malondialdehyde levels in liver and kidney tissues

\begin{tabular}{lccc} 
& Group I & Group II & Group III \\
$\begin{array}{l}\text { Liver } \\
\text { SOD } \\
\text { (U/mg protein) }\end{array}$ & $26.98 \pm 3.49$ & $16.31 \pm 1.92$ & $22.29 \pm 1.78$ \\
$\begin{array}{l}\text { GSH } \\
\text { (nmol/mg protein) }\end{array}$ & $4.27 \pm 0.59$ & $2.79 \pm 0.43$ & $3.74 \pm 0.57$ \\
$\begin{array}{l}\mathrm{MDA} \\
\text { (nmol/mg protein) }\end{array}$ & $1.67 \pm 0.27$ & $6.09 \pm 0.64$ & $3.93 \pm 0.58$ \\
$\begin{array}{l}\text { Kidney } \\
\text { SOD } \\
\text { (U/mg protein) }\end{array}$ & $60.10 \pm 5.7$ & $28.50 \pm 3.94$ & $45.68 \pm 4.94$ \\
$\begin{array}{l}\text { GSH } \\
\text { (nmol/mg protein) }\end{array}$ & $2.64 \pm 0.22$ & $1.23 \pm 0.24$ & $2.02 \pm 0.34$ \\
$\begin{array}{l}\text { MDA } \\
\text { (nmol/mg protein) }\end{array}$ & $1.42 \pm 0.16$ & $3.85 \pm 0.47$ & $2.49 \pm 0.42$ \\
\hline
\end{tabular}

Data are expressed mean \pm SD. P versus group I with group II and group II with group III and group I with group III. $p<0.05$ was considered statistically significant.

SOD: Superoxide dismutase; GSH: Glutathione; MDA: Malondialdehyde.

individuals and patients are often exposed to ionizing radiation during medical procedures that involve diagnosis and treatment of tumors.[11] Ionizing radiation is employed for the treatment of cancer as well as in angiography and various imaging protocols. However, the radiation exposure causes undesirable side-effects. For instance, ionizing radiation has been shown to cause DNA damage that result in cell death and neoplastic conversion of the cells. $[12,13]$ Ionizing radiation therapy has been reported to increase the production of highly reactive free radicals at the cellular level.[2,3] It reacts with biological molecules such as proteins, lipid, and DNA to produce fatal outcomes in the cells.[14] As a result, free radicals adversely affect the activity of antioxidant enzymes, including SOD, which are known to catalyze the conversion of superoxide radicals into $\mathrm{H}_{2} \mathrm{O}_{2}$ and $\mathrm{O}_{2}$, which weakens the antioxidant defense systems at the cellular level.[12,15] Oxidative species such as MDA, a lipid peroxidation end-product, can be produced during ionizing radiation procedures. Various methods for alleviating or eliminating oxidative damage resultant from ionizing radiation have been investigated previously.[16-18] Decreases in the SOD levels and in the activities of various antioxidant enzyme activities together with increased levels of MDA have been reported in the kidney, lung, and thyroid tissues as well as in the plasma due to exposure to ionizing radiation.[17,18] Our study findings revealed an increase in the MDA concentrations accompanied by a decrease in the antioxidant enzyme levels in the liver and kidney tissues due to exposure to ionizing radiation. In addition, apoptosis has been implicated in cell death caused by ionizing radiation in several studies.[19] The reaction of free radicals with direct genetic material in the cells results in various forms of DNA base damage, and 8-OHdG produced during this process is one of the most commonly observed products. 8-OHdG has been described as an important marker of DNA damage both in vivo and in vivo.[20] Our findings revealed an increase in the 8-OHdG expression levels in the renal tissues of rats exposed to ionizing radiation in the present study. Thymol treatment also significantly alleviated the 8-OHdG expression in kidney tissues. Thymol is a typical oxidative damage marker in the living cells. The defense mechanism that functions to destroy damaged cells, known as apoptosis or programmed cell death, has also been reported to be effective in protecting cells against DNA damage. However, ionizing radiation affects the defense system in cells to initiate the apoptotic signaling pathway resulting from severe DNA damage.[21-24] Caspases have been demonstrated to assume a critical function in the delivery of apoptotic signals in the cells. A previous study also reported higher caspase- 3 activity in colonic tissues due to exposure to ionizing radiations.[25] In addition, the caspase-3 expression in liver tissues was exacerbated in ionized-radiation-treated rats in our study. However, the caspase-3 expression was reduced by thymol treatment. In addition to our biochemical and immunohistochemical findings, data on oxidative tissue damage was also supported by the pathological findings. In other words, the results of the examination of the pathological tissues and other results are mutually compatible.

Thymol scavenges intensive free radicals produced in various experimental models.[26,27] Thymol also exhibits antibacterial, anti-inflammatory, antifungal, and radioprotective effects.[27,28] Our results showed that thymol may be useful in diagnostic or therapeutic protocols for the attenuation of oxidative tissue damages caused via the ionizing radiation therapy. However, there are several limitations to this study. For instance, previous studies and our own data indicate that ionizing radiation therapy, which is frequently employed for a variety of purposes in a clinical setting, may induce oxidative stress responses by forming hazardous metabolites and weakening the antioxidant defense system. However, our results indicate that thymol may be a promising agent for preventing or decreasing oxidative tissue damage due to ionizing radiation ther- 
apy. Nonetheless, further scientific studies, including randomized controlled trials, are warranted to validate our findings in a relevant clinical setting.

Peer-review: Externally peer-reviewed.

Conflict of Interest: The authors declare no conflicts of interest

Ethics Committee Approval: This experimental study was approved by the Atatürk University Local Animal Ethics Committee (27.04.2018/114), and the experimental procedures were conducted at the Atatürk University Medical Faculty Department of Radiation Oncology, the Veterinary Faculty Pathology Laboratory, the Faculty of Pharmacy Biochemistry Laboratory, and the Experimental Animal Research and Application Center (ATADEM), Turkey.

Financial Support: The authors declare that this study received no financial support.

Authorship contributions: Concept - H.K.Ö.; Design - H.K.Ö., F.N.E.A.; Supervision - H.K.Ö., F.N.E.A., A.T.; Funding - None; Materials - H.K.Ö., F.N.E.A., A.T.; Data collection and/or processing - H.K.Ö., S.Y., Y.B., G.E., A.K., Y.Ş.; Data analysis and/or interpretation - H.K.Ö., S.Y., Y.B., G.E., A.K., Y.Ş.; Literature search - H.K.Ö., F.N.E.A.; Writing - H.K.Ö.; Critical review - H.K.Ö., F.N.E.A.

\section{References}

1. Mishra K, Alsbeih G. Appraisal of biochemical classes of radioprotectors: evidence, current status and guidelines for future development. 3 Biotech 2017;7(5):292.

2. Bourhis J1, Blanchard P, Maillard E, Brizel DM, Movsas B, Buentzel J, et al. Effect of amifostine on survival among patients treated with radiotherapy: a meta-analysis of individual patient data. J Clin Oncol 2011;29(18):2590-7.

3. Najafi M, Cheki M, Hassanzadeh G, Amini P, Shabeeb D, Musa AE. The Radioprotective Effect of Combination of Melatonin and Metformin on Rat Duodenum Damage Induced by Ionizing Radiation: A Histological Study. Free Radic Biol Med 2019;145:161-74.

4. Sanchez ME, Turina AD, Garcia DA, Nolan MV, Perillo MA. Surface activity of thymol: implications for an eventual pharmacological activity. Colloids and Surfaces B-Biointerfaces 2004;34(2):77-86.

5. Fachini-Queiroz FC, Kummer R, Estevão-Silva CF, Carvalho MD, Cunha JM, Grespan R, et al. Effects of Thymol and Carvacrol, Constituents of Thymus vulgaris L. Essential Oil, on the Inflammatory Response. Evidence-Based Complementary and Alternative Medicine 2012;2012:657026.

6. LLana-Ruiz-Cabello M, Maisanaba S, Puerto M, Pri- eto Al, Pichardo S, Jos Á, et al. Evaluation of the mutagenicity and genotoxic potential of carvacrol and thymol using the Ames Salmonella test and alkaline, Endo III- and FPG-modified comet assays with the human cell line Caco-2. Food and Chemical Toxicology 2014;72:122-8.

7. Nagoor Meeran MF, Jagadeesh GS, Selvaraj P. Thymol, a dietary monoterpene phenol abrogates mitochondrial dysfunction in beta adrenergic agonist induced myocardial infarcted rats by inhibiting oxidative stress. Chem Biol Interact 2016;244:159-68.

8. Ohkawa H, Ohishi N, Yagi K. Assay for lipid peroxides in animal tissues by thiobarbituric acid reaction. Anal Biochem 1979;95:351-8.

9. Sedlak J, Lindsay RH. Estimation of total, proteinbound, and nonprotein sulfhydryl groups in tissue with Ellman's reagent. Anal Biochem 1968;25(1):192205.

10. Sun Y, Oberley LW, Li Y. A simple method for clinical assay of superoxide dismutase. Clin Chem 1988;34:497-500.

11. Ward JF. Radical thinking. Nature 1988;331:128.

12. Carante MP, Altieri S, Bortolussi S, Postuma I, Protti $\mathrm{N}$, Ballarini F. Modeling radiation-induced cell death: role of different levels of DNA damage clustering. Radiation and Environmental Biophysics 2015;54(3):30516.

13. Cerutti PA. Prooxidant States and Tumor Promotion. Science 1985;227:375-81.

14. Rani V, Deep G, Singh RK, Palle K, Yadav UC. Oxidative stress and metabolic disorders: Pathogenesis and therapeutic strategies. Life Sciences 2016;148:183-93.

15. Mccord JM. Superoxide-Dismutase: an Enzymic Function for Erythrocuprei (Hemocuprein). Citation Classic 1981:17.

16. El-Missiry MA, Fayed TA, El-Sawy MR, El-Sayed AA. Ameliorative effect of melatonin against gamma irradiation- induced oxidative stress and tissue injury. Ecotoxicology and Environmental Safety 2007;66(2):27886.

17. Kutanis D, Erturk E, Besir A, Demirci Y, Kayir S, Akdoğan A, et al. Dexmedetomidine acts as an oxidative damage prophylactic in rats exposed to ionizing radiation. Journal of Clinical Anesthesia 2016;34:577-85.

18. Lee JH, Park JW. Oxalomalate regulates ionizing radiation-induced apoptosis in mice. Free Radical Biology and Medicine 2007;42(1):44-51.

19. Chen YR, Wang XP, Templeton D, Davis RJ, Tan TH. The role of c-Jun N-terminal kinase (JNK) in apoptosis induced by ultraviolet $\mathrm{C}$ and gamma radiation. $\mathrm{Du}-$ ration of JNK activation may determine cell death and proliferation. Journal of Biological Chemistry 1996; 271(50):31929-36.

20. Park JW, Floyd RA. Lipid-Peroxidation Products 
Mediate the Formation of 8-Hydroxydeoxyguanosine in DNA. Free Radical Biology and Medicine 1992;12(4):245-50.

21. Kaina B. DNA damage-triggered apoptosis: critical role of DNA repair, double-strand breaks, cell proliferation and signaling. Biochemical Pharmacology 2003;66(8):1547-54.

22. Okamoto M, Koga S, Tatsuka M. Differential regulation of caspase- 9 by ionizing radiation- and UV-induced apoptotic pathways in thymic cells. Mutation Research-Fundamental and Molecular Mechanisms of Mutagenesis 2010;688(1-2):78-87.

23. Roos WP, Kaina B. DNA damage-induced cell death by apoptosis. Trends in Molecular Medicine 2006;12(9):440-50.

24. Woo M, Hakem R, Soengas MS, Duncan GS, Shahinian A, Kägi D, et al. Essential contribution of caspase 3 CPP32 to apoptosis and its associated nuclear changes. Genes \& Development 1998;12(6):806-19.
25. Guven B, Can M, Piskin O, Aydin BG, Karakaya K, Elmas $\mathrm{O}$, et al. Flavonoids protect colon against radiation induced colitis. Regul Toxicol Pharmacol 2019;104:128-32.

26. Chauhan AK, Kang SC. Therapeutic potential and mechanism of thymol action against ethanol-induced gastric mucosal injury in rat model. Alcohol 2015;49(7):739-45.

27. Meeran MFN, Prince PSM. Protective effects of thymol on altered plasma lipid peroxidation and nonenzymic antioxidants in isoproterenol-induced myocardial infarcted rats. Journal of Biochemical and Molecular Toxicology 2012;26(9):368-73.

28. Islam MT, Khalipha ABR, Bagchi R, Mondal M, Smrity SZ, Uddin SJ, et al. Anticancer activity of thymol: A literature-based review and docking study with Emphasis on its anticancer mechanisms. International Union of Biochemistry and Molecular Biology 2018;71(1):9-19. 